\title{
AN ANALYSIS OF STUDIES ON SIBERIAN HISTORY, CULTURE, ARCHEOLOGY AND CIVILIZATION ${ }^{1}$
}

\author{
Illyas Topsakal ${ }^{2}$
}

\begin{abstract}
Especially at last few years there are lots of Siberia Region's history, archeology, language and culture studies in America and West Europae and the communities living in Siberia are one of the most trendy subjects of collective studies of different universities. In Turkey linguists have started to study about this area and current linguistics studies are about this region's dialects. But history studies about Siberia, especially after 17 th century are quite a little. To analyze Russian studies and materials about this region can be taught starting point of filling this gap. This study is a project about analysis of Russian archieve materials and studies on this region from 17 th century to 1960 and finished last year.
\end{abstract}

Keywords: Siberia History, Russian History, Altai, Yakut, Tuva, Hakas, Şor, Siberia Natives.

Topsakal, İlyas. "An Analysis Of Studies On Siberian History, Culture, Archeology And Civilization". Siberian Studies (SAD) 2.6 (2014): 122.

Topsakal, İ. (2014). An Analysis Of Studies On Siberian History, Culture, Archeology And Civilization. Siberian Studies (SAD), 2 (6), s.1-22.

\footnotetext{
${ }^{1}$ This project has been supported by Istanbul University Scientific Research Projects Agency ${ }^{2}$ Assoc. Prof., Istanbul University Faculty Of Divinity Depratment of Islamic History and Fine Arts.ilyastopsakal@yahoo.com
} 


\title{
SIBIRRY'NIN TARIHI, KÜLTÜRÜ, ARKEOLOJISI VE MEDENIYETI ÜZERINE YAPILAN ÇALIŞMALARIN BIR ANALIZi
}

\begin{abstract}
ÖZET
Özellikle son y1llarda, Amerika ve Batı Avrupa'da Sibirya Bölgesine ait tarih, arkeoloji, dil ve kültür alanındaki çalışmalara sık rastlanılmakta; bilhassa Sibirya'da yaşayan halklar, çeşitli üniversitelerin ortak çalışmalarına konu olmaktadır. Ülkemizde de özellikle dilcilerimiz tarafından çalışılmaya başlanmış, bölgenin lehçeleri ve diyalektleri üzerinde hayli araştırma yapılmıştır. Ancak alanda ülkemizde yapılan tarihi çalışmalar, özellikle 17. yüzyıl sonrası için oldukça sınırlıdır. Ülkemizdeki bu boşluğu doldurabilmek için Rusların bölge üzerinde yaptığı çalışmalar ve bıraktıkları arşiv malzemelerini tanımak ve analiz etmek başlangıç olarak düşünülebilir. Bu çalışma öncelikle Rusların 17. yüzyıldan 1960'lı yıllara kadar bölgede bıraktığı resmi arşiv malzemeleri ve bilimsel çalışmaları analiz etmek üzere bir proje olarak başlamış ve geçtiğimiz yıl başarıyla bitirilmiştir. Çalışmanın amacı; alanda yapılacak bilimsel çalışmalara yarayacak malzemenin içeriğini, analiz yöntemi kullanarak araştırmacıya sunabilmektir.
\end{abstract}

Anahtar Kelimeler: Sibirya Tarihi, Rus Tarihi, Altay, Yakut, Tuva, Hakas, Şor, Sibirya Yerlileri. 
Modern local historians attribute the historiography of Siberia to the records collected in Siberian Office ${ }^{1}$ which was founded when the area was invaded by Russia and was thus officialized in $1637 \mathrm{AD}$. They tend to refer to the pre-russian period via archeological findings. As a matter of fact, studies conducted in pre- and post-soviet periods clearly show this distinction. Archives of central governments which ruled Siberia especially from late $17^{\text {th }}$ century on contain very important data on the area. Various correspondence, official reports, pictures drawn by explorers, scripts found in local and central bureaus, maps, documents, winter camps, explorations, problems on land administration needs, their diplomatic and strategical solutions, official reports on mineral explorations and administration were the first things coming to mind.

Being the most prominent element in etnographic history, systematic mapping studies which developed through tracking cronological order technique have continued since late $16^{\text {th }}$ century. Route drawing of rivers, including Obi river in western Siberia, started in 1667 AD. Composite drawings of Siberia were made continuously in 1673 , between 1684 and 1687 and finally during whole $17^{\text {th }}$ century. Non-mathematical drawings of S. U Remezov, one of the most prominent cartographers of Russia, consist of valuable information for starters. ${ }^{2}$

Beginning in late $16^{\text {th }}$ century and continuing through $17^{\text {th }}$ century, annexation of Siberia into Russia was of the prime importance for the Russian Empire. The most prominent figure in this period was Yermak and the Cossacks in his army. Another important fact was the spread of intellectually developing Orthodox movements, which can be called Orthodoxization of Siberia. Esipov and Stroganov are two important sources on this period. ${ }^{3}$

Following the initial century, works by Yermak started to produce conceptual terms about history of the area and his stories were mainly focused on his army. Works by Yu N. Krizhanich, S. Spafariy and Remezov from late $17^{\text {th }}$ century were more complex and loaded pieces compared to previous ones. The socioeconomic matters of the city Tobol at that time, for instance, can be found in Yu. Krizhanic's work named Politics (Sobraniye Sochneniy, 1891: 10).

In Tsardom period Russian historiography, the most significant driving force behind the annexation of $17^{\text {th }}$ century Siberia is proposed to be Christianity. As an ongoing story, this medieval ideology is very well reflected in YU Krizhanich and S.U. Remezov's works as the central theme (Sibirskiye Letopisi, 1907; Kratkaya Sibirskaya, 1880). Among the initial sources, written in late $17^{\text {th }}$ century by the order of Peter the Great, The Atlas of Siberia and The History of Siberia were two important examples consisting of valuable historical, geographical and etnographic 
data (Andreyev, 1960: 116-117). The History of Siberia mentions about the importance of the education of Christianity for the well-being of the state in autocratic Russia and defend this argument by giving information about local mythology (İstoriya Sibiri, 1968: 7). Again it can be said that N. Wilsen's Northern and Eastern Tartary have had an important role in teaching about Siberia to westerners. ${ }^{4}$

Systematical scientific studies on Siberia began in early $18^{\text {th }}$ century, in Peter the Great's rule (1672-1725). These studies, mainly exploratory campaigns, helped create an enormous amount of data for foreign policy and public domain on Siberian history, geography and ethnography. Throughout $18^{\text {th }}$ century, there were more studies on Siberia than other regions of Russian Empire. Geographical studies focused towards north ranging from the Arctic Sea to the Pacific. From there, these explorations were aimed to reach Irtysh River basin in India. The most important data of these explorations, the one by Kirilov the First (1734), was published in 1745 by the Academy of Sciences (Krylov, 1948). ${ }^{5}$ The first scientific exploration was followed by first (1725-1743) and second (1768-1774) campaigns to Kamchatka. Scientist from Moscow State University, P. Pallas, J. Falk and Lepekhin, organized an enormous expedition which had a huge global impact especially on history of culture in North-western Siberia and published their findings afterwards (İstoriya Sibiri, 1968: 17;). ${ }^{6}$

The history of the wast area between the Pacific, Mongolia and the North Sea, so to say the history of Siberia, has long been the attraction of the western and Russian scientists. The main reason for this interest is most probably the natural sources and riches of the area. Even after the Cossack leader, Yermak, merchant noble families of Russia competed in their exploratory expeditions in the area, which in return help the leading families gain prominence by the Tsar. The guardians of these exploration and invasion campaigns were the Cossaks, who basicly enabled the turning point in Russian history in the east. According to Bakhrushin (1937), the first expedition by Mueller provided the first hand data for those who study in this area.

Gerhard Frederick Mueller's “The Conquest of Siberia and The History of the Transactions, Wars, Commerce, \&C. \& C. Carried on Between Russia and China, From The Earliest Period"7 provided undoubtedly the most valuable data and contribution for those scientists who studied $17^{\text {th }}$ and $18^{\text {th }}$ centuries. The first edition of the book was published in 1842 in Cambridge. According to the viewpoint of the period, Siberia, due to its gold reserves, had extraordinary natural resources. This 
resource became the most important factor in the development course of the Russian state. For Russian Tsars and rulers, Siberia was considered an area where small primitive tribes were settled. Thus this area was also considered very easy to invade and control in order to maintain the financial development of Russia. This view compromises the viewpoint of other western researchers and explorers. Historians like S. P. Krasheninnikov, M. V. Lomonosov, A. N. Radishchev did their research on the purpose of exloiting the over- and underground riches of Siberia.

Among the primary resources on the history and ethnography of Siberia, the study of Tatischev is probably the most important one. V. N. Tatishchev created an extensive survey with an geographical, historical, etnographic, archeological, linguistic and antropological content; and he sent it to the administrative districts of Kazan. This survey put its stamp on history as the first document collecting official information about the people of Siberia. V. N. Tatishchev, later, finished and published his work "The History of Russia".

In the meanwhile, Mueller created the Siberian scientific archive with incoming documents and he managed to systemize them in a chronological order. The Kamchatka Campaign in $18^{\text {th }}$ century supplied G. F. Mueller with scientific data on this topic. It can be said that Mueller did bring the most valuable data and documents about the history of Siberia to St. Petersburg. Although the very first attempt of classification belongs to Tatishchev, it was Mueller's achievement to classify these studies, put them into a chronological order and analyze them. Hence G. F. Mueller's work "The History of Siberia" had a considerable impact on the government and later historians. ${ }^{9}$

Beside the general studies conducted on the historyof Siberia in $18^{\text {th }}$ century, there were other studies on local people. As a classic on this topic published in 1756 AD, S. P. Krashennikov's "Description of the Land of Kamchatka" has been translated into English, French, German and Dutch and it is still the primary resource on the ethnography and history of Kamchatka. ${ }^{10}$

The first study trip to Siberia and the North Pacific Polar regions was made in $18^{\text {th }}$ century. At this time, Russian researchers depicted Russian geographical explorations in the North and Northwest as historic discoveries. In this context, M. V. Lomonosov deserves mentioning beside F. Mueller due to his important feasibility and exploration work on the North Sea route. In the early $19^{\text {th }}$ century, Russian explorers, I. Krusentern and F. Litke in North-east Pacific; and F. Wrangel in Siberia, collected the first etnohistorical data on local dwellers. In the $18^{\text {th }}$ century, the sources for the history of Siberia were already structured on scientific criticism and the steps of historical course were clearly identified; thus the historical 
infrastructure was completed. At the end of $18^{\text {th }}$ century, the historical and statistical data on Siberia which began to be created by N. I. Novikov was published in a book named "Ancient Russian Vivliofike".

Since the beginning of the $19^{\text {th }}$ century, Siberia has faced dramatica changes with gradual economic and social development. The collector of 1818 Siberian sources, G. I. Spassky, began to publish "The Siberian Journal" in St. Petersburg including several Siberia chronicles and historical data. ${ }^{12}$ In the meantime, the Moscow Telegraph began to address Siberia with "The Notes of Fatherland".

In the $18^{\text {th }}$ century, the travel notes of Mueller on Siberia contributed crucial details to the history and geography of the area and pioneered the studies conducted in the West. ${ }^{13}$ The travel notes of Mueller not only caused a constantly growing interest in the area but also helped the scientific research on the area to grow in numbers. Later on, the problems of Siberian history was handled with regard to the Russian and World history. Slotsov, in his "Historical Review of Siberia" in which he studied Siberian archeology, history and ethnography, made a critical review of the area historically and sociologically and as a result he left very important materials for local historians. ${ }^{14} \mathrm{P}$. A. Slovtsov's work was followed by Sherlov's "A Chronological List of Data from the History of Siberia 1032-1882". ${ }^{15}$

Siberian historian P. A. Slovtsov (1767-1843) finished his book "Historical Review of Siberia 1838-1844" in Tobolsk where he spent most of his life. In his work, he tried to give information about the first Russian settlement in the area as much chronologically as possible and he aimed at revealing the unknown side of Russian colonization by giving all of local, administrative, economic and cultural life in the area. He used statistical research methods in his works. By succesfully publishing local needs, P. A. Slovtsov had a huge impact on the development of political thought in Siberia. He was later declared the ideological father of patriotism emerging in $1860 \mathrm{~s}$ in the area. ${ }^{16}$ It is a widely accepted fact that Decemberists had an impact on the development of social though in Siberia. Their ideas and articles on local newspapers had importan role in $19^{\text {th }}$ century Siberia. Decemberists were a group promoting the democratic ideas of national culture. That's why they supported not only the needs of the Bourgeoisie, but also those of local people and their cultural development. While N. A. Bestuzev studied the Buryats, G. S. Batenkov researched the impact of Russian immigration on the working population in the area. ${ }^{17}$ 
Especially the socialist historians have criticized this period as a time when the Capitalist policy of oppressing and exploiting lower classes was thoroughly applied. Siberia makes 40 percent of Asia, which is one fifth of the total area in the world. It made 60 percent of the USSR. This area supplies more than 75 percent of natural resources of Russia. 90 percent of coal, 60 percent of hydroelectrical resources, 90 percent of petroleum, natural gas, gold and silver, all of northern traditional riches such as fur and the like are produced in this area. Over- and underground riches of Siberia are globally known. This kind of abundance of riches can be compared with Canada. However, despite the abundance, Canadian wealth is limited due to its smaller territory. Japanese president, Kobe Setatsu, once mentioned these underground resources in Pravda while explaining the importance of Siberia for the future of Japan. ${ }^{18}$

According to a 1959 census in the USSR, the population of the the area according to its tribal ethnonym was as follows: 23.558.000 including Tyumen, Kurgan and Far East. 19.607.000 of these were Russian, 1.221.500 Ukrainians, 1.223.600 Turkic, Mongol, Tungusic, Ugric and Samoyedic dwellers. The Turkic rooted population was 859.000 and to put it in detail: 232.200 of it was Yakut, 99.800 Tuvan, 56.000 Khakas, 44.600 Altay, 14.900 Shorian, 3.900 Dolgan, 500 Tofa and 407.100 Tatar. Tungus-Manchu people were 45.700. Of these, 24.500 Ewenki, 9000 Lamut, 8000 Nanai, 2000 Ulch and 1300 Udege. Orochs, Oroks and other smaller ethnic minorities had very small numbers of people.

Among the Mongolian rooted people, there were 251.500 Buryats, 22.800 Samoyedic language speaking Nenets, 3.700 Selkups, 19.200 Khanits and 6.300 Mansis. In the North-east Asia, belonging to no groups above, there were 25.700 people including Koryaks, Yukaghirs, Itelmens and Aleuts by the Yenisei River; and Nivkhs by the Amur River. There is no doubt that this numbers and classifications were done by Russian researchers and it reflects the perception of another nation for us. The numbers and classes will change in ethnonymical studies done on these tribes from the viewpoint of the Turkish history.

The opinion that local people of Siberia were exploited for a long time by the Tsardom has been a valid view for European sources as well as for Soviet historians. ${ }^{19}$ Soviet historians, however, claim that the administrative methods during the Soviet regime stopped the exploitation of these people, which is an issue deserving a comparative analysis. Moreover, population exchange, forced migration and turning local people into minorities in their motherland were problematic issues for both regimes and periods. Another alleged success story of the Soviet regime, creation of autonomous republics, has been another recent political issue which deserves further research. In this period, autonomous regions and republics such as 
Buryatia, Yakutia, Kemerovo Oblast, Tuva, Khakassia, Chukchi have been founded and some important studies on these countries have been published.

At the second half of the $19^{\text {th }}$ century, social developments in Russia made an impact on Siberian histography and significant differences emerged in writing. S. M. Solovyev ${ }^{20}$ and Kluchevsky ${ }^{21}$ who put forward the geographical factors and factors of settlement have been noted as the most important authors in this period but A. P. Shapov's ${ }^{22} 1850-70$ idea of a democratic state started to get ahead against S. M Solovyev's theory of State School the role of a self-sufficient state. On the one hand A. P Shapov, tried to put forward the social and colonialist nature of government policy in Siberia and on the other hand he tried to determine the role of colonization in the development. The Slavist view, which centers the Russian Nationalism based on etnographic and anthropological material, was an overview of the state that was continuously processed in the lives of Russian people. (Okladnikov, 1968)

Regional reflections of these discussions to Siberia is directly related to its position to serve as an open prison for political criminals. Especially G. N. Potanin and N.Yadrintsev ${ }^{23}$ wrote important works including ethnographic studies of indigenous peoples that marked on Siberia's socialist history. Yadrintsev in his work named "How Siberia Was Colonized", touched on problems such as: places of indigenous peoples at state and economy, colonization movement, ways of cultural development and impact of viewpoints, colonial policy of the Tsarist government. ${ }^{24}$ "Historical Information on the graph M. Speranskii in Siberia," prepared by V. I. Vagin is an important resource for Siberia used in the west containing large and rich archival material. $^{25}$

At the end of the $19^{\text {th }}$ century N. N Ogloblin's four volume work of archeology was published with the name of "Siberian Office Writings and Article Reviews" (1592-1768). ${ }^{26}$ Still, this work retains the distinction of being the richest reference book for Siberia in Russia. This work published in XIX. century is also very important in terms of the fact that it includes the monographs in the period from the end of $16^{\text {th }}$ century to the beginning of $18^{\text {th }}$ century.

Sharing and management of land in Siberian region and the placement of new immigration are the majors of the thorny issues in the history of the region. The most striking researches are: "The First Settlers in Siberia and Their Lives, 1889" and "Mangaze in Siberian History and The History of Town of Mangaze" by P. N. Butsinskogo. ${ }^{27}$ These works are important to see the archives as they include new 
materials. I. V. Pupin, has managed to summarize the history of Siberia of the $20^{\text {th }}$ century in his famous four volume work "History of Russian Ethnograph". ${ }^{28}$

Historians of the Soviet Union showed success and failure in this region by rewriting the history of these peoples. The unique requirements of this area was presented to the World of science with extensive studies on different fields such as; various archives, linguistic, folk poetry, ethnographical and anthropological. By the end of 1920's, the well-known Soviet historian S. V Bakhrushin ${ }^{29}$ became a role model for historians with the study he made to reveal the history of Siberian peoples in the $17^{\text {th }}$ century and with the use of a method of using documentary and archives. Following that B. O. Dolgikh ${ }^{30}$ published his work "Genetic and Tribal Composition of Peoples of Siberia in XVII. Century" in 1960 based on archive materials and basic etnographic data. Additionaly, some of the other Soviet scientist combining documentary and ethnographic resources: S. A Tokarev, L. P Potapov, M. G. Levin A. P. Okladnikov, N. N. Stepanov, I. S. Vdovin, I. S. Gurvich can be regarded as prominent researchers of this period.

1930s and '40s and the post-war period witnessed important developments in scientific and social lifes of Altai, Khakases, Tuva, Sakhas(Yakutia), Mongolian, Buryat and other peoples living in the region. In this respect, there are some prominent studies on the subject and these can be listed as below: "Essay on History of West Buryat-Mongolians between XVII-XVIII. centuries, $1937^{31}$, by A. P. Okladnikov: Historian and monographist; "Buryat-Mangolian History from XVII. Century to the 60. Year of XIX. Century",1940, by F. A. Kurdyavtsev; "A Brief History of Buryat-Mongolian People", 1942, by P. T. Khapteyeva; " Social Life of Yakuts (Sakha) - XVII-XVIII Centuries", 1945"32, by S. A Tokarev; "Essays on Altai History", 1953, and "Origin and Natinalization of Khakases", 1957, by L. P. Potapov $^{33}$; "Ethnic History of Nort-East Siberia"34, 1966, by I. S. Gurvich. These works reveal that, the mistakes Russian State did in the past with the nationalist and bourgeous understanding lead to anger in the region and all these studies mentioned above had the basic Dynamics that, actually in terms of the development of the region, the necessity of the participation to the Russian State Union is known and it will come true with socialist point of view. "Peoples of The World - Peoples of Siberia "1956, edited by M. Levin and L. P. Potapov and "Ethnographic Atlas of Siberia" by M. G. Levin and L.P. Potapov" are two important works that had important function in promotion and study of Siberian peoples. ${ }^{35}$

S. V. Bakhruşin first started to study the positive and negative impacts of the Russion migration on Siberia in 1920 according to archive material in hand and aimed to reveal impacts of settlement in 17. and 18. centuries on political and cultural lives. In his work "Essays on Colonization History of Siberia in XVI and 
XVII Centuries" Moscow $1927^{36}$, S. V. Bakhrushin talks about region's integration process with Russia and its cultural situations. Also it is possible to find popular subjects such as: roads used from European Russia to the region, points of colonization, economic and administrative system and summary of the occupation. Especially, in the description of the economic process Bakhrushin is ahead of the others.

After the war, Soviet Siberian studies speeded up and developed further. V. I. Shunkov mentions about agricultural power of Siberia in his works "Essays on Colonization History of Siberia in the beginning of XVII-XVIII. Centuries" 1946, and "Essays on History of Agriculture in Siberia"(XVII. y.y.) ${ }^{37}$ published in 1956. These works are extremely important to show the actual role of the masses and to evaluate the extent of Russian Colonization on agriculture. These studies continued later. "Agricultural Land of İlima" I-II, $1949-1957 ;^{38}$ by V. N. Sherstoboev, "Population in Tomsk Region at The First Half of XVII Century", $1950 ;{ }^{39}$ by Z. Ya. Boyarshinova, "Settlement of Villagers in The Basin of İlima and Leni in the 17. Century", 1956, and "Russian Villagers in Yakutia" (XVII. Century and beginning of XX. century), $1961 ;{ }^{40}$ by F. G. Safranov, "West Siberia in 18.Century: Russian Population and Agricultural Development" $1965 ;{ }^{41}$ "Russians in 17 th century Yenisei Basin", $1965,{ }^{42}$ by A. N. Kopilov are first of these studies to come in mind. These studies are important and "to be seen" resources for Scientists who research and study '17th century Siberia'.

Soviet Historians tried to make studies centering the positive contribution of settlement in Siberian history therefore to examine the movements of population is important for recent historians and researchers. In this field V. A. Aleksandrov puplished his monograph: "Russian Population in Siberia at the beginning of 17th and 18th century" in $1964^{43}$. This monograph is important in terms of to reveal residential areas of Russian population, their relations with the natives and their contribution and damage to the economic life.

O. N. Vilkov's work named "Trade and Craftsman in West Siberia", $1967,{ }^{44}$ contains important information about economic life, customs-related legislations and relations with neighboring countries of newly formed city of Tobolsk.

Finally in the post-war years Soviet scientists returned to $19^{\text {th }}$ and early $20^{\text {th }}$ century researches, scientific discovery of Siberia. Discovery of the North Sea, interiors of Siberia and Pacific by Russian sailors in 17th and 18th century has been 
subject for numerous research. Important ones of these are A. I Andreev, A. V. Efimov, B. O. Dolgikh, M. O. Kosven, L. S. Berg, L. A. Goldenberg, V. I. Grekov, M. I. Belov, V. A. Divina etc. They revealed a new rich archive including maps in the area of discovery of Siberia. "Siberia and North-West America in XVII-XVIII. Centuries, Discovery Atlas "45 edited by A. V. Efimov was published in 1964. There are 194 cards and archive materials about Siberia in this book. This work is also interesting in terms of the fact that it shows the sophistication of geographical terms used by Russian globetrotters as well as their knowledge of mapping

"Siberia Through the Eyes of the Western Travelers" (XIII-XVI) 1941, ${ }^{46}$ by M. P. Alekseev gave information about the past of Siberia and more importantly ensured diversity. As for A. I. Andreev, he made analyses of important data for Soviet-Siberian Studies by making research and resource cristicism in his work "Essays on Siberian Researches" 1940-1960". 47

"The addition of the development of Siberia and in the historical literature Siberia, 17th. Century (1960)" "48 by V. G. Mirzoev follower of S. V. Bakhruşin, the founder of the Synthesis Historiogaphy, and "Russian folklore in Siberia, 1962",49 by Y. R. Kosheleva can be accepted as the first folklore researches of the region.

"The Peoples of Siberia"50 published under the editorship of M. G. Levin and L. P. Potapov can be considered among the important works to study on Peoples of Siberia in USA and other countries. Okladnikov's work "Population and Culture of Antique Siberia" and monographies of M. G. Levin, S. İ. Rudenko and A. P. Okladnikov have been resources on Siberian ethnology and archeology for western researchers. ${ }^{51}$ Also, works of Lengyel and Ervin are prominent studies for Siberian history and especially Russian Tsarist period. ${ }^{52}$

Another researcher from far east Japan, Kato Kyudzo, and his work "Siberian History" contains important information about Japanese and Russian history and it is important for Siberian history as well. ${ }^{53}$ "Brief History of Siberia to the Beginning of 19. Century" published in İkutsk by Ogorodnikov is another resource referenced in particular. ${ }^{54}$

However; "İstoriya Sibiri" "55 which is an abstract of all these studies and prepared by a large team of academics, stands out as an outstanding study covering and exceeding all the studies done so far about the region and it is a first to look reference book for today's studiest about Siberian history. It was published as 5 volumes and famous Russian Archeolog A. P. Oklodnikov headed the project.

Oklodnikov, summerized the formation of this project as followed: 
"Historians, ethnographers, linguists brought out this work collectively together with all the researchers. Archaeologists, anthtopogists, economists, linguists from Moscow and Leningrad; scientists from Novosibirsk, Tomsk, Irkutsk, UlanUde, Yakutsk and most of the Siberian cities, (Vladivostok, Blagoveshchensk, Omsk, Kemerovo) worked in this project. It was quiet difficult for scientist to work on the same subject and field and engage around the same thought. Both the greatness of the research area and the examination of the wide range of time period, since the history of mankind to the present, made things difficult and the distance as well. Additionaly, the difficulty of obtaining sources and documents and lack of documents were significant shortcomings." (p.20)

First volume of the book is about the period before the invasion of Siberia by Russia. It starts with the history of the region 25.000 years ago. Siberian history examines Stone Age and Paleolithic cultures, oldest cars known today and Russian migrations beyond Urals in-depth. Particularly, ethnpgraphy, anthropology, language and related material based on new archeological data and quaternary geological data aims to enlighten the historical processes of Peoples of Siberia. In the second volume; the spread of Russians on the vast territory of Russian state from Urals to Pacific ocean including Siberia takes place. Also; cultural and economic relation between indigenous peoples of Siberia, geographical discoveries, tsarist regime, way of administration in Siberia, caste struggles, identities and cultural structure are among the topics of this volume.

Third volume handles the time period untill the capitalism comes to the endpoint in Siberia (1861-1917). All the events in this period that bring out the Bolshevik violation are widely dealt with. The topics discussed in this volume are such: Economic and culturual development of Russian population, indigeneous peoples of Siberia and their social and political lives, relations within themselves, struggles of workers, oppression and exploitation, support of the villagers to Peoples of Siberia in their national independence struggle against revolutionary activities of Bolshevik forces. The organization of the first movement of revolutionists (19051907) are widely discussed here as well.

Volume four covers the period starting from a certain line 1917 to 1937. Great October victory considered as the start by Russian violators and many primary sources of this period, socialist revolution, struggle in the establishment process of Soviet power, civil war, White and Red army fight are subjects taking place in this 
volume. This volume is also an excellent source to study the history of agricultural collectives and a reference book about the development of industry and culture in the industrialization period of USSR.

Volume five examines years between 1937-1965 in chronological order. Great Land War of Soviet Union, Participation of Siberians to this war, support of the workers, the great victory and economic success are the subjects that are discussed and presented to the reader in this volume.

\section{BIBLIOGRAPY}

Andreyev, A. İ. Oçerki po istoçnikovedeniyu Sibiri. Vol. I. XVII, M-L., 1960.

Andreyeviç, V. K. İstoriçeski oçerk Sibiri. Vol. I-II. Spb. 1889.

Alekseeva, M.P. Sibir v izvestiyakh zapadnoevropeyskikh puteşestvennikov i pisateley. izd. 2-e. İrkutsk. 1941.

Aleksandrov, V. A. Russkoe naselenie Sibiri XVII- naçala XVIII. Moskva, 1964.

Azbelev, S. N. and Zaşitu Truzda Vasiliya Nikitiça Tatişeva. Cbornik Ruskovo istoriçeskovo obşestva. İnstitut rossiskoy istorii RAN. M. Russkaya panaroma. 2011. T., 11; (159).

Bakhrushin, S. V. Ocerki po istorii kolonizatsii Sibirii v XVI v XVII vv. Moskva, 1927.

Bakhruşin, S. V. Oçerkakh po istorii kolonizasyii Sibiri v XVII i XVII vv. M.: İzdanye M., S., Sabaşnikovıkh, 1927.

Bakhruşin, S. V. and G. F. Mueller. Kak istorik Sibiri. V kn.: G. F. Mueller, İstoriya Sibiri, T. I. M.-L., 1937.

Batenkov, Gavriil Stepanovich. O spominaniia i rasskazy deiatelei tainykh obshchestv 1820-kh gg. vol. 2. Moscow, 1933. Vosstanie dekabristov: Materialy, vol. 8. Moscow-Leningrad, 1925.

Boyarshinova Z.Ya. Naselenye Tomskogo uezda v pervoy polovine XVII v. Tr. / Tomskii un-t. 1950.T.1.

Butsinskiy, P. N. Zaseleniya Sibiri i bit pervıkh ee naselnikov Tipografiya Guberskogo II Ravleniya Kharkov, 1889.; K İstorii Sibiri Mangazeya i Mangazeyskiy uyezd, 1893.

Chertecnaya kniga Sibiri. Sostavlanya Tobolskim synom Boyarskim Remozovim v 1701 godu. St Petersburg, 1882.

L. A. Goldensberg. Semyon Ulvanoviç Remezov Sibirski kartograf i geograf 1642-posli 1720. Moscow, 1965. 
Dolgikh, B. O. Rodovoy i plemennoy sostav naradov Sibiri v XVII. veka, M. 1960; "The Origins of the Nganasans: Preliminary Remarks," in Studies in Siberian Ethnogenesis, H. N. Michael (ed.), Toronto: Arctic Institute of North America/University of Toronto Press, (1962), 220-299.

Dolgikh and Potapov. L.P. Migratsiia naseleniia i etnicheskie protsessy. In: A.P. Okladnikov et al. Istoriia Sibiri: Sibir' v Sostave Feodal'noi Rossii. Tom 2: 55-60. 1968.

Efimov, V., Atlas geografiçeskikh otkrıtiy v Sibiri i v severo-zapadnoy Amerike XVII XVIII vv. İzd-vo Nauka, 1964.

Gromıko, M. M. Zapadnaya Sibir v XVII veka russkoe naselenye i zemledelçeskoe osvoenye. İzd-vo Nauka, 1965.

Gurvich, S. Etnicheskaya istoriia severo-vostoka Sibiri. Moskva, 1966.

İstoriya Sibiri. T. I, II, III, IV, V. İzdatelstvo nauka. Leningrad, 1968.

Kapılov, A.N. Russkye na Yenisey XVII v. Novosibirsk, 1965.

Koşeleva, Y.G. Russkaya fol'kloristika Sibiri. Tomsk, 1962.

Kraşennikov, S. P. (Akademiay nauk) Opsaniye zemli Kamçatki. Peterburg, 1755.

G. F. Steller. Opisaniye zemli Kamçatki. Frankfurt. Leipzing, 1774.

Krylov, İ. K. "Atlas of the Russian Empire", Vserossiyskiy Atlas İvana Krilova (17261734), Trudı Pervogo Soveşaniya po istorii estoestvoznaniya 24-26 dek. 1946 g.; Pod red. Çl.-kor., AN SSSR, X .M.- L., 1948.

Sibirskie letopisi. SPb. St. Petersburg. 1907; Kratkaya Sibirskaya letopis' (Kungurskaia). St. Petersburg, 1880.

Kyutzo, Kato. Istoriya Sibiriya. Tokyo, 1963, 212 str. (in the Japanese language). 1956.- 1114 str.

Levin M. and L. P Potapov. Narodı mira - Narodı Sibiri. M-L., İzdatelstvo AN SSSR,

Levin, M. G. and Potapov, L.P. İstoriko-etnografiçeskii Atlas Sibiri. Moskva, 1961.

Levin, M. G. and L. P. Potapov (editors). The Peoples of Siberia, Chicago, 1964.

Lengyel, Emil. Siberia. New York, 1943.

Lessner, Ervin. Gradle of Conquerors of Siberia. New York, 1955. 
Mirzoev, V. G. Prisoedinenye i osvoenye Sibiri v istoriçeskoi literature XVII veka. İzdvo socialno-ekonomiçeskoi literatury. Moskova, 1960.

Mueller, G. F. İstoriya Sibiri T. I., M.-L. 1937; T. II, M.- L., 1941.

Mueller, Gerhard Friedrich and Palas, Peter Simon. The Conguest of Siberia and the History of the Transaction, wars, Commerce, etc. Carried on between Russia and China, from the Earliest Period, this edition first publihed 1842; Cambridge University Pres, Cambridge 2010.

Novikov, V.İ. Drevniya Ruskiye Vivliofike,.Vip. Vtoroye, Moskov, 1788.

Narodı Sibiri. M.-L., 1956; İstoriya Yakutskoy ASSR, T.1., M-L., 1955; T. 2, M., 1957; T. 3. M., 1963; İstoriya Buryatskoy ASSR, C. 1-2; Ulan-Ude, 1959; İstoriya Tuv1, C. I; M., 1964;

Ogorodnikov, V.I. Oçerk istorii Sibiri do naçala XIX v., çl. 1. İrkutsk, 1920.

Ogloblin, N. N. Obozroniye stolbtsov i knig Sibirskogo prikaza 1592-1768 gg., Dokument1 voyevodskogo upravleniya. M. 1895.

Okladnikov, A.P. Ancient Population of Siberia and its Culture. Chicago, 1964.

Okladnikov, P. Oçerki iz istorii istorii zapadnıkh buryt-mongolov, XVII-XVIII vv. Leningrad, 1937.

Oçerk istorii naroda. M. 1940; Obşestvenniy stroy yakutov. M.Yakutskoe gos.izdvo,1945. Etnografiya narodov SSSR. İzd-vo Mosk. Un-ta, 1958. Perevedena na it.yazıkS.A.Tokarev URSS: popoli e costume. Bari, Editori Laterza, 1969.

Pravda, 28 Oktyabrya 1965

1892.

Pypin, A. N. History of Russian Ethnography, "Belarus and Siberia" T. 4. St. Petersburg,

Safranov, F. G., Krestyanskaya kolonizasiya basseynov Lenı i İlima v XVII v, Yakutsk. Kn. İzd-vo, 1956. str. 210; Russkye krestyane v yakutii. Yakutsk,1961.

Sobraniye sochneniy 1. (Jan 1891, St. Petersburg).

Sibirskiye letopisi. St. Petersburg, 1907; Kratkaya Sibirskaya letopis (Kungurskaya).St. Petersburg, 1880.

Tatişev, V. N. İstoriya Rossiskaya. 4 T., M. 1964.

Slovtsov, P. A. İstoriçeskoye obozroniye Sibiri, kniga pervaya s 1585 по 1742 g. Spb., 1886; kniga vtoroya s 1742 po 1823 g. Spb., 1888. 
Sherlov, İ. V. Khornologiçeskiy pereçen vajneyşıkh dannıkh iz istorii Sibiri 1032-1882 gg. İrkutsk, 1884.

Shunkov, V. I. Oçerki po istorii kolonizasyii Sibiri v XVII - naçale XVII v. Oçerkakh po istorii zemledeliya Sibiri (XVII v.), 1956.

Sherstoboev, V.N. İlimskaya paşnya. T. I-II, 1949-1957

The unabridged text of Istoriia Rossii s drevneishikh vremen (History of Russia From Earliest Times), first published in St. Petersburg, 1851-1879, in 29 volumes, translated in 50 volumes from the Moscow edition of 1959-1966.

A History of Russia (4 Volumes). J. M. Dent/E.P. Dutton, London/NY, 1911.

Yandrentsev, N. M., Sibir kak Koloniya, K yubileyu trekh stoletiya: sovremennaya Sibir, yeya nujdi potrebnosti, yeya proşloye i buduşeye, St. Petersburg, 1882.

Vagin, V. İstoriçeskiye svedeniya o deyatilnosti grafa M. M.Speranskogo v Sibiri s 1819 po 1822 gadu, T. 2; Snp. 1872.

Vilkov, O. N. Remeslo i torgovlya Zapadnoi Sibiri v XVII v. İzd-vo Nauka. M. 1967.

Witsen, N. Noord en Oost Tartarye, (Amsterdam MDCCV. First print: Amsterdam, 1692; Second edition: Amsterdam, 1705. Reprint in 1785.

1 “Сибирском приказе” in Russian language

${ }^{2}$ Chertecnaya kniga Sibiri, Sostavlanya Tobolskim synom Boyarskim Remozovim v 1701 godu, St Petersburg 1882; L. A. Goldensberg, Semyon Ulvanoviç Remezov Sibirski kartograf i geograf 1642-posli 1720, Moskov 1965.

3 Sibirskie letopisi. SPb, St. Petersburg, 1907; Kratkaya Sibirskaya letopis' (Kungurskaia). St. Petersburg, 1880; Russian chronicles about the history of Siberia that were compiled from the late 16th to the 18th century. The Esipov, Kungur, Remezov, Stroganov, and other Siberian chronicles are a basic source for the early history of Russian Siberia. Several chronicles were compiled later: I. Cherepanov's Notes for Siberian History and New Siberian Chronicle, P. Pezhemskii's Chronicle of the City of Irkutsk From 1652 to the Present, and A. I. Kytmanov's Short Chronicle of the Eniseisk and Turukhansk Regions of Eniseisk Province (15941893). In all, more than 40 Siberian chronicles are known to have been written. Historians have offered various solutions to problems pertaining to the origin, 
authenticity, and interrelationship of the Siberian chronicles (A. I. Andreev, A. A. Vvedenskii). The generally accepted theory of the development of Siberian chronicle writing was proposed by S. V. Bakhrushin. According to Bakhrushin, the nucleus of the Siberian chronicles is the no longer extant Description of How to Reach Siberia, written in 1621 by participants in Ermak's campaigns. This work was the basis for the Synodic of the Tobol'sk Cathedral, written in 1622. Making use of both the Description and the Synodic. S. Esipov compiled a chronicle in 1636. Written in the mid-17th century, the Stroganov Chronicle incorporated the Description and material from the archives of the Stroganovs (a merchant family) but was not directly linked with the Esipov Chronicle. The Kungur Chronicle was written between the late 16th and second half of the 17th centuries. It relies heavily on tales told by participants in Ermak's campaign and on folk legends of the late 16th century. The Remezov Chronicle was written in the late 17th century. At this time the Description of the New Lands of the Siberian State was written by Nikifor Veniukov, working independently. There are other views on the origin of the Siberian chronicles.

${ }^{4}$ N. Witsen, Noord en Oost Tartarye, Ofte Bondig Ontwerp Van eenig dier Landen en Volken Welke voormaels bekent zijn geweest. Beneffens verscheide tot noch toe onbekende, en meest nooit voorheen beschreve Tartersche en Nabuurige Gewesten, Landstreeken, Steden, Rivieren, en Plaetzen, in de Noorder en Oosterlykste Gedeelten Van Asia En Europa Verdeelt in twee Stukken, Met der zelviger Landkaerten: mitsgaders, onderscheide Afbeeldingen van Steden, Drachten, enz. Zedert naeuwkeurig onderzoek van veele Jaren, door eigen ondervondinge ontworpen, beschreven, geteekent, en in 't licht gegeven (Amsterdam MDCCV. First print: Amsterdam, 1692; Second edition: Amsterdam, 1705. Reprint in 1785).

5 İ. K. Krylov, "Atlas of the Russian Empire", Vserossiyskiy atlas İvana Krilova (1726-1734), Trudı Pervogo Soveşaniya po istorii estoestvoznaniya 24-26 dek. 1946 g.;Pod red. Çl.-kor., AN SSSR, X .M.- L., 1948.

${ }^{6}$ N. G. Akademik I. I. Lepekhin i ego puteshestviia po Rossii v 1768-1773 gg. [2nd ed.]. Moscow, 1953, İvan İvanoviç Lepekhin (1740-1802), investigated the Volga Region, the Urals, and the north of European Russia. In 1773 he journeyed through the Baltic Region and Byelorussia. In 1783 he became permanent secretary of the Russian Academy. Lepekhin was the author of works on botany, zoology, Russian philology, and other subjects. He expressed advanced ideas on permanent changes on the earth's surface, on the causes of cave formation, and on changes in plants and animals caused by the environment. His principal work was a description of the 1768-72 expedition. Through Various Provinces of the Russian State (vols. 1-3, 1771-80; vol. 4, 1805), this work contains much factual data on the geography and ethnology of Russia. 
${ }^{7}$ Mueller, G. F. \& Palas, P. S. The Conguest of Siberia and the History of the Transaction, wars, Commerce, etc. Carried on between Russia and China, from the Earliest Period, this edition first publihed 1842; Cambridge University Pres, Cambridge 2010.

${ }^{8}$ V. N. Tatişev, İstoriya Rossiskaya, Vol. 4, M. 1964;

${ }^{9}$ G. F. Mueller, İstoriya Sibiri, T. I., M.-L., 1937; Vol. II, M.- L., 1941.

${ }^{10}$ S. P. Kraşennikov (Akademiay nauk) Opsaniye zemli Kamçatki, Peterburg, 1755; G. F. Steller, Opisaniye zemli Kamçatki, Frankfurt; Leipzing, 1774; Krasheninnikov was to study plants, animals and minerals, but in addition he developed a strong interest in Siberian history and geography. During the early part of the expedition, he accompanied professor Gmelin on the travel through the Urals and western Siberia to Yeniseysk. He made numerous observations of natural history, ethnology and linguistics, e.g. records of Evenki (tungus) and Buryat vocabulary. From Bering's headquarters at Yakutsk, the expedition professors Gmelin and Gerhard Friedrich Mueller sent Krasheninnikov ahead to Okhotsk and Kamchatka to build house and make preliminary observations. Thus, he became the member of the expedition with the most extensive knowledge of the peninsula. He published his observations in 1755 ("Описание земли Камчатки";English translation by James Grieve (1764) as History of Kamtschatka. However, he drew extensively on the manuscripts of the deceased Georg Wilhelm Steller. Apart from detailed accounts of the plants and animals of the region, there also were reports on the language and culture of the indigenous Itelmen and Koryak peoples, who he reportedly got along extremely well with.

${ }^{11}$ V.İ., Novikov, Drevniya Ruskiye Vivliofike, Bask1 2, Moskov 1788.

${ }^{12}$ It was named "Asian Journal" in 1827

${ }^{13}$ Gerhard Friedrich Mueller, Peter Simon Palas, The Conguest of Siberia and the History of the Transaction, wars, Commerce, etc. Carried on between Russia and China, from the Earliest Period, this edition first publihed 1842; Cambridge University Pres, Cambridge 2010.

${ }^{14}$ P. A. Slovtsov, İstoriçeskoye obozroniye Sibiri, kniga pervaya s 1585 po $1742 \mathrm{~g}$. Spb., 1886; kniga vtoroya s 1742 po 1823 g. Spb., 1888.

${ }^{15}$ I. V. Sherlov, Khornologiçeskiy pereçen vajneyşıkh dannıkh iz istorii Sibiri 1032 1882 gg. İrkutsk, 1884.

${ }^{16}$ P. A. Slovtsov, İstoriçeskoye obozroniye Sibiri, kniga pervaya s 1585 po $1742 \mathrm{y}$. Spb., 1886; kniga vtoroya s 1742 po 1823 g. Spb., 1888. 
17 Gavriil Stepanovich Batenkov, Ospominaniia $i$ rasskazy deiatelei tainykh obshchestv 1820-kh gg., vol. II, Moscow, 1933. Vosstanie dekabristov: Materialy, vol. 8. Moscow-Leningrad, 1925.

${ }^{18}$ Pravda, October 28th, 1965.

${ }^{19}$ Narodı Sibiri, M.-L., 1956; Istoriya Yakutskoy ASSR, T.1., M-L., 1955; T. 2, M., 1957; T. 3. M., 1963; İstoriya Buryatskoy ASSR, T. 1-2; Ulan-Ude, 1959; Istoriya Tuvı, Vol. I-II; M., 1964;

${ }^{20}$ The unabridged text of Istoriia Rossii s drevneishikh vremen (History of Russia From Earliest Times), first published in St. Petersburg, 1851-1879, in 29 volumes, translated in 50 volumes from the Moscow edition of 1959-1966.

${ }^{21}$ A History of Russia, (4 Volumes), J. M. Dent/E.P. Dutton, London/NY, 1911

${ }^{22}$ Afanasii Prokof'evich Shchapov; Soch., vols. 1-3. St. Petersburg, 1906-08; Sobr. soch.: Dopolnit. torn k izdaniiu. Irkutsk, 1937;

"Neizdannye soch." Izvestiia Obshchestva arkheologü, istorii i etnografii pri

Kazanskom un-te, vol. 33, issues 2-3. Kazan, 1926;

A. P. Shchapov v Irkutske: Neizdannye materialy. Irkutsk 1938; Born Oct. 5 (17),

1831, in the village of Anga, Verkholensk District, Irkutsk Province; died Feb. 27

(Mar. 10), 1876, in Irkutsk. Russian historian and publicist.The son of a sexton, Shchapov studied at the Kazan Theological Academy from 1852 to 1856; he graduated with a baccalaureate degree. He taught Russian history at the theological academy from 1856 to 1860 and at Kazan University in 1860 and 1861. On Apr. 16, 1861, he delivered a revolutionary speech at a requiem for the victims of the Bezdna uprising of 1861; he was arrested and sent to St. Petersburg. After an investigation Shchapov was prohibited from teaching and was appointed an official for sectarian affairs in the Ministry of the Interior. In 1862 he was dismissed from his position and put under police supervision.hchapov was a contributor to such journals as Otechestvennye Zapiski, Russkoe slovo, Vremia, and Vek. Exiled to Siberia in 1864 on suspicion of being associated with A. I. Herzen and N. P. Ogarev, he went first to Anga and then to Irkutsk. In 1866 he served as an ethnographer on an expedition to Turukhansk Krai conducted by the Siberian Department of the Russian Geographic Society. In the summer of 1865, Shchapov was arrested in connection with the case of the Siberian oblastniki(revolutionary group of Siberian intellectuals). After his release he became a contributor to the journals Delo and Zapiski Sibirskogo otdela RGO (Notes of the Siberian Department of the Russian Geographic Society). He died of tuberculosis. Shchapov wrote many works on the history of sectarianism and the schism (raskol), which he viewed as expressions of popular protest against social oppression. From 1856 to 1864, under the influence of G. Z. Eliseev and S. V. Eshevskii, he supported thezemstvooblast theory, which was accepted in Russian demographic historiography and 
which viewed the history of Russia from the standpoint of the interrelationships of separate areas ("oblasts"). Later, while in exile, Shchapov subjected the theory to criticism; influenced by the ideas of N. G. Chernyshevskii, D. I. Pisarev, H. T. Buckle, and the positivists, he attempted to apply the methods of natural science to the study of the history of the development of the Russian people.

${ }^{22}$ In 1889 under contract with Russian Geographical Society N. Yadrintsev traveled to Mongolia, where he located the remains of Early Middle Age city Hara - Balgas and the ancient Mongolian capital Karakorum. In the Kosho-Tsaidam gorge (valley of the Orkhon river) N.Yadrintsev found two petroglyphic monuments with runiform writing of ancient Türks of the 6-8th centuries, later decoded by the Danish scientist W.Tomsen. These discoveries brought N.Yadrintsev a world fame, and became the greatest scientific sensation of the 19th century. In a quick succession, already in the 1891 was organized a follow-up Orhon expedition of the Russian Academy of Sciences with participation of N.Yadrintsev, led by an ethnically German native from Barnaul, a recognized Turkologist academician W.W.Radloff. The Orhon expedition found more monuments of runiform writing with epitaphs of the Türkic kagans and other nobility. The results of the expedition were published by W.W.Radloff in the "Atlas of Mongolia antiquities" (1892-1893) and in aspecial collection of works of the Orhon expedition (1892).

${ }^{23}$ In 1889 under contract with Russian Geographical Society N. Yadrintsev traveled to Mongolia, where he located the remains of Early Middle Age city Hara - Balgas and the ancient Mongolian capital Karakorum. In the Kosho-Tsaidam gorge (valley of the Orkhon river) N.Yadrintsev found two petroglyphic monuments with runiform writing of ancient Türks of the 6-8th centuries, later decoded by the Danish scientist W.Tomsen. These discoveries brought N.Yadrintsev a world fame, and became the greatest scientific sensation of the 19th century. In a quick succession, already in the 1891 was organized a follow-up Orhon expedition of the Russian Academy of Sciences with participation of N.Yadrintsev, led by an ethnically German native from Barnaul, a recognized Turkologist academician W.W.Radloff. The Orhon expedition found more monuments of runiform writing with epitaphs of the Türkic kagans and other nobility. The results of the expedition were published by W.W.Radloff in the "Atlas of Mongolia antiquities" (1892-1893) and in aspecial collection of works of the Orhon expedition (1892).

${ }^{24}$ N . M. Yandrentsev, Sibir kak Koloniya, K yubileyu trekh stoletiya: sovremennaya Sibir, yeya nujdi potrebnosti, yeya proşloye i buduşeye, St. Petersburg, 1882.

${ }^{25} \mathrm{~V}$. Vagin, İstoriçeskiye svedeniya o deyatilnosti grafa M. M.Speranskogo v Sibiri s 1819 po $1822 \mathrm{~g}$, I-II, 1872. 
${ }^{26}$ N. N. Ogloblin, Obozroniye stolbtsov i knig Sibirskogo prikaza 1592-1768 gg., Dokumentr voyevodskogo upravleniya, Moskva 1895.

27 P. N. Butsinskiy, Zaseleniya Sibiri $i$ bit pervıkh ee naselnikov Tipografiya Guberskogo II Ravleniya Kharkov, 1889.; K Ístorii Sibiri Mangazeya $i$ Mangazeyskiy uyezd, 1893.

${ }^{28}$ A. N. Pypin, History of Russian Ethnography I-IV, St. Petersburg, 1892.

${ }^{29} \mathrm{~S}$. V. Bakhrushin, Ocerki po istorii kolonizatsii Sibirii v XVI v XVII vv. Moskov, 1927.

${ }^{30}$ B. O., Dolgikh, Rodovoy i plemennoy sostav naradov Sibiri v XV v., M. 1960.

31 A. P. Okladnikov, Oçerki iz istorii istorii zapadnıkh Buryat-Mongolov, XVIIXVIII vv., Leningrad 1937.

${ }^{32}$ S.A. Tokarev, Obşestvenniy stori Yakutov, Yakutsk State Printing, 1945.

33 L. P. Potapov, Ocherki po istorii altaytsev. Moskva, 1953; Proiskhojdenye i formirovanie Khakassoi narodnosti, Abakan,1957.s 307; The peoples of South Siberia (popular edition), Novosibirsk, 1953, 192 p.; "Tuva" The peoples of Siberia, Ed. M.G Levin and L. P Potapov, Leningrad: (Publishing House of the USSR Academy of Sciences), 1956; p. 420-473; "Khakases" The peoples of Siberia, (Ed. M.G. Levin and L. P Potapov), Leningrad: Publishing House of the USSR Academy of Sciences, 1956, p. 376-420; "Shor", The peoples of Siberia, (Ed. M. G Levin and L. P Potapov), Leningrad: Publishing House of the USSR Academy of Sciences, 1956, p. 492-529; The Turkic peoples of Southern Siberia in VI-VIII centuries, History of Siberia, M., 1964. T. I, p.266-284.

${ }^{34}$ I. S. Gurvich, Etnicheskaya istoriia severo-vostoka Sibiri, Moskva 1966.

${ }^{35}$ M. Levin ve L. P Potapov, «Narodı mira - Narodı Sibiri.M-L., İzdatelstvo AN SSSR, 1956.- 1114 s.. M. G. Levin ve L.P. Potapov, «İstoriko-etnografiçeskii atlas Sibiri» M., 1961.

${ }^{36} \mathrm{~S}$. V. Bakhruşin Oçerkakh po istorii kolonizasyii Sibiri v XVII i XVII vv. M.: İzdanye M i S. Sabaşnikovıkh, 1927. p. 198.

37 V. I. Şunkov, Oçerki po istorii kolonizasyii Sibiri v XVII - naçale XVII v. Oçerkakh po istorii zemledeliya Sibiri (XVII v.), 1956.

${ }^{38}$ V.N. Sherstoboev, İlimskaya paşnya., Vol. I-II, 1949-1957

${ }^{39}$ Z.Ya. Boyarshinova Naselenye Tomskogo uezda v pervoy polovine XVII v. Tr. / Tomskii un-t. 1950.T. 112.

${ }^{40}$ F. G. Safranov, Krestyanskaya kolonizasiya basseynov Lenı i İlima v XVII v, Yakutsk. Kn. İzd-vo, 1956. S. 210. İ Russkye khrestyane v yakutii. Yakutsk,1961. p. 495.

${ }^{41}$ M.M.Gromıko. Zapadnaya Sibir v XVII vek, russkoe naselenye i zemledelçeskoe osvoenye.,Baskı Nauka, 1965

${ }^{42}$ A.N. Kap1lov. Russkye na Yenisey XVII v.,Novosibirsk.1965. pp. 31-57. 
${ }^{43}$ V. A. Aleksandrov, Russkoe naselenie Sibiri XVII- naçala XVIII v. Moskva,1964. ${ }^{44}$ O. N. Vilkov Remeslo i torgovlya Zapadnoi Sibiri v XVII v. Bask1 Nauka., M., 1967

${ }^{45}$ A. V. Efimov Atlas geografiçeskikh otkrttiy v Sibiri i v severo-zapadnoy Amerike XVII - XVIII vv. Bask1 Nauka, 1964

46 M.P.Alekseeva, Sibir $v$ izvestiyakh zapadnoevropeyskikh puteşestvennikov $i$ pisateley, izd. 2-e, İrkutsk, 1941.

${ }^{47}$ A. İ. Andreev Oçerkax po istoçnikovdeniu Sibiri, M-L, 1960 . p.223

${ }^{48}$ V. G. Mirzoev, Prisoedinenye i osvoenye Sibiri v istoriçeskoi literature XVII c, İzd-vo socialno-ekonomiçeskoi literatury, Moskva 1960.

${ }^{49}$ Y.G. Koşeleva, Russkaya fol'kloristika Sibiri. Tomsk, 1962.

${ }^{50}$ M. G. Levin and L. P. Potapov (editors), The Peoples of Siberia, Chicago 1964.

${ }^{51}$ A.P. Oklodnikov, Ancient Population of Siberia and its Culture, Chicago1964; M. G. Levin. Ethnic Origins of the Peoples of Northeastern Asia, Arctic Institute of North America. "Anthropology of the North: Translations from Russian Sources", № 3, Toronto, 1963; S. I. Rudenko. The Ancient Cultures of the Bering Sea and The Eskimo Problem. "Anthropology of the North: Translations from Russian Sources", Toronto, 1962; H. N. Michael (editor). The Archaeology and Geomorphology of Northern Asia: Selected Works. Arctic Institute of North America. "Anthropology of Toronto press", 1964; A. P. Okladnikov. The Soviet Far East in Antiquity. An Archaeological and Historical Study of the Maritime Region of the USSR. Arctic Institute of North America. "Anthropology of the North:. Translations from Russian Sources”, № 6, Toronto. 1965.

${ }^{52}$ Emil Lengyel, Siberia, New York, 1943; Ervin Lessner, Gradle of Conquerors of Siberia, New York, 1955.

${ }^{53}$ Kato Kyutzo, Istoriya Sibiriya, Tokyo 1963, p. 212. (in Japanese language).

${ }^{54}$ V. I. Ogorodnikov, Oçerk istorii Sibiri do naçala XIX v. İrkutsk, 1920

${ }^{55}$ İstoriya Sibiri, Vols. I, II, III, IV, V, İzdatelstvo Nauka, Leningrad 1968 